\title{
Comparative Prospective Study -Currette vs Powered Instrument Microdebrider Assisted Adenoidectomy- A Study of 25 Cases
}

\author{
Authors \\ Dr Jitesh Kumar Garg MBBS MS ENT ${ }^{1^{*}}$, Dr H.S.Bhui ${ }^{2}$, Dr A. K. Gupta ${ }^{3}$ \\ ${ }^{1}$ Address: 216 Padmavati Colony-B, New Sanganer Road Jaipur 302019 \\ ${ }^{2}$ Professor RNT Medical College Udaipur, \\ ${ }^{3}$ Senior Professor, Geetanjali Medical College Hospital Jaipur \\ *Corresponding Author \\ Dr Jitesh Kumar Garg MBBS MS ENT \\ Email: drjitesh.garg79@gmail.com
}

\section{Introduction}

Infectious and inflammatory diseases involving the pharynx, tonsils, and adenoids account for a significant proportion of childhood illnesses and pediatric health care expenditure. They often result two of the most common surgical procedures of childhood -tonsillectomy \& adenoidectomy. Recent clinical research has helped to illuminate this vast area of pediatric otorhinolaryngology including the effect of adenotonsillar hypertrophy on obstructive sleep apnea, the microbiologic flora of the tonsils and adenoids and their role in chronic adenotonsillar hypertrophy, the relationship between adenotonsillar hypertrophy and craniofacial growth and the new technique for adenotonsillectomy with improved management of perioperative morbidity.

This work review our current understanding of new technique for adenoidectomy via microdebrider and conventional currette mathod.

\section{Development of Adenoids}

The adnoids develops in close association with mucous glands ${ }^{1}$. As early as the third month of development, glandular primordial are visible as solid buds surrounded by blood vessels and increasing number of discrete lymphoid cells in a louse parenchyma. During the fourth month, lymphatic vessels appear and glandular primordial increase in number. These folds are covered with a typical respiratory epithilium of pseudostrtified ciliated epithilium with goblet cells. Further evidence of function of these tissues was reported by slipka ${ }^{2}$, who demonstrated that $\operatorname{IgA}, \operatorname{IgG}$ and IgM were all present in epipharyngeal tissue taken from 5 to 16 week old human embryos.

\section{Anatomy of Adenoids}

The adenoids is visible in later fetal life and then increase in size until the sixth to seventh year of life, after which time it frequently atrophies. this adenoid consist of a single pyramidally shaped aggregation of lymphoid tissue with its apex 
pointed towards the nasal septum and the base to the roof and posterior wall of the nasopharynx.

The blood supply and drainage are from the ascending pharyngeal artery, the ascending palatine and tonsillar branch of the facial artery, the pharyngeal branch of maxillary artery, the artery of pterigoid canal and contributing branches from the tonsillar branch of the facial artery.

\section{Role of Adenoid as Defense System of the Body}

The adenoid and tonsils are predominantly B -cell organs, ample evidence shows that the adenoids and tonsils are involved in inducing secretory immunity and regulating secretory immunoglobulin production. Adenoids are designed for direct transport of foreign material from the exterior to the lymphoid cells ${ }^{3}$. This is in contrast to lymph nodes which depends on antigenic delivery through afferent lymphatics. The tonsils and adenoids rank among the secondary lymphatic organs. Their defence mechanism eliminate weak, antigenic signals. Only when additional higher antigenic concentration are presented does proliferation of antigenic sensitive B cells occurs in the germinal centers3. Low antigen does effect the differentiation of lymphocytes to plasma cells: whereas high antigen doses produce B cells proliferation. The generation of $\mathrm{B}$ cells in the germinal of the tonsil and adenoid is considered by siegels to be are of the most important function 6 . $\mathrm{T}$-cell function such as interferon -g production and presumably production of other important lymphokines have been shown to be present in adenoids and tonsils ${ }^{7}$.

Recurrent tonsillitis and adenoid hyperplasia causes inflammation of the reticular crypts epithilium results in shedding of immunologically active cells and decreasing antigen transport function with subsequent replacement by stratified sqamous epithelium ${ }^{8,9}$.

These changes lead to reduced activation of the local B -cell system, decreased antibody production and an overall reduction in density of the B-cell and germanal centers in extrafollicular $\operatorname{areas}^{10}$.

Reports conflicts regarding the immunological consequences of tonsillectomy and adenoidectomy, yet it is clear that no major immunological deficiency results from these procedures $^{11}$. ogra $^{12}$ showed a three to fourfold drop in titers in children previously immunised with live polio virus vaccine.

Serum IgA levels in post tonsillectomy patients were lower than in age matched controls, but the immunological changes did not appear to be clinically significant ${ }^{13,14}$.

Children who were previosly immunised orally with live polio vaccine dropped their titers three to fourfold after adenodectomy and tonsillectomy 15. Attempts to vaccinate seronegetive children subjected to tonsillectomy and adenoidectomy have resulted in delayed and lowered nasopharyngeal secretory immune response as measured by $\operatorname{IgA}$ antibodies to polio virus ${ }^{3}$.

\section{Clinical Microbiology of Waldeyer S Ring}

Estiblishment of normal flora in the upper respiratory tract begins at birth. actinomyces, fusobacterium and nocardia are acquired by 6 to 8 months of age ${ }^{16}$. Susequently bacteroides, leptotrichid, propionibacteriunt, and candida are also established as part of oral flora ${ }^{13,17}$. Fusobacterum population reach high numbers after dentition and reach maximal numbers at one year of age ${ }^{13}$.

Healthy children up to 5 years of age can harbor known aerobic pathogens. ingvarsson, lundgren and irving revealed that streptococcus pneumoniae was recovered in $19 \%$ of healthy children, hemophyllus influenzae in $13 \%$,group A streptococcus in 5\% and M.catarrhalis in $36 \%$.

\section{Effects of Enlarge Adenoids}

\section{A. Upper Airway Obstruction}

Chronic adenoid hypertrophy is a common cause of upper air way obstruction in children and in severe cases may result in corpulmonale, pulmonary vascular hypertention and alveolar hypoventilation all of which may be reversed by 
adenoidectomy.

It is important to elicit the severity of symptomatology by obtaining a thorough history from the patient s primary care giver. findings that suggestive of significant sleep disturbance include witnessed apneic episodes, excessively loud snoring, chronic mouth breathing, hypersomnalence, enuresis, nightmares, poor school performence, hyponasal speech, failure to thrive caused by enlarge adenoids ${ }^{22}$.

\section{B. Affect Over Craniofacial Growth}

Chronic mouth breating secondary to adenoid hyprtrophy has shown to affect craniofacial growth patterens in children. as early as 1872 , Tomes 24 that children who were chronic mouth breathers secondary to adenoid hypertrophy displayed evidence of malocclusion and maxillofacial growth abnormalities .

Linder Aronson Woodside, Lundstrom 25 demonstrated the classical stigmata of adenoids facies in children with chronic nasopharyngeal obstruction from adenoid hypertrophy.

\section{Otitis Media with Effusion}

Diagnostic Assessment of Adenoid Hypertrphy Lateral neck rediograph may be helpful in assessing adenoid hypertrophy. Fujika, Young, Girdomy determined that adenoid nasopharyngeal ratio measured by lateral neck radiograph they categories the three grades based on the side of adenoid pad - grad I,II,III.

Flexible endoscopic nasopharyngoscopy may also be valuable in assessment of adenoids.

\section{Techniques For Adenoidectomy}

I. Adenoid Curettes Using Laforce Adenotome, II. Adenoidectomy by Coblation Device

III. Denoidectomy by Angled Blade of Microdebrider

\section{Complications}
A. Postoperative Hemorrhage
B. Velopharyngeal Insufficiency
C. Nasopharyngeal Stenosis

D. Cervical Spine Complication- Grisel S Syndrome

\section{Aims and Objectives}

A. Study Design: Comparative Prospective Study

B. Objectives: In the following study our aim is to compare curette verses powered assisted microdebrider adenoidectomy in terms of different outcomes variables like operational efficacy of procedure, operating time, dlood loss, hemostasis time, post operatve pain.

\section{Materials and Methods}

We compared the cases of adenoid hypertrophy prospectively by performing adenoidectomy via two approach one curette adenoidectomy and the other microdebrider assisted adenoidectomy .We compared the both procedures in terms of operational efficacy, operating time, blood loss,complication and relief from preoperative symptoms in follow up period.

Before undegoing for surgery every case was studied in details about history of complains, examination of nose, throat, ear, general physical examination, radiological assessment and coagulative profile.

Morbidity in peri and post operative period and one year of post operative follow up was assessed in both the categories.

\section{Surgical indication of adenoidectomy}

Infection- purulent adenoiditis, adenoid hypertrophy associated with otitis media with effusion, chronic recurrent otitis media,

Obstruction - adenoid hypertrophy associated with excessive snoring and mouth breating, craniofacial growth abnormalities,

Other- suspected neoplasia, adenoid hypertrophy with sinusitis

History- Detailed history of all the patient was taken on following basis

Upper airway obstruction: snoring, apenic spells, enuersis, failure to thrive, day time somnalence, hyponasality whether the above complain are present or not and if present the frequency, duration etc were asked, 


\section{Poor dentition, problem related to ear, nose}

Examination- Detailed examination of ear, nose throat was performed on every patient before taking for surgery. All the positive points of history was confirmed by examination and if needed further investigation was done. Every patient was looked for adenoid faces, high arch palate, protusive maxilla, dental malocclusion, pinched nostrils. Both the ears were examined for wax, status of tympanic membrane whether retracted or bulged, presence of effusion in middle ear, tunning fork test showing conductive deafness etc. Anterior rhinoscopy was done in each patient. In systemic examination cardiopulmonary examination was done.

\section{Investigations}

X-ray lateral neck was done to every patient, $\mathrm{x}$ ray pns, pure tone audiogram and impedence tympanometry, x-ray chest and ECG was done as required. Routine blood investigation $\mathrm{CBC}, \mathrm{BT}$, CT, PT were done to all patients. Child below 3 years was not considered for surgery as of low blood volume. All the cases were done under general anesthesia. All the work was done under general anesthesia between 2005 to 2007 in ENT department RNT medical college udaipur.We performed adenoidectomy via two procedure one curette and other microdebrider assisted adenoidectomy.

The curette adenoidectomy was performed with laforce adenotome.

Microdebrider is a powered instument and angled blade was used for adenoidectomy. 3000 to 6000 rpm speed was used.

Following parameter were looked during the operative procedure-adenoid removal time, total operative time, amount of blood loss. On every post op visit child \& parents were inquired as per questionnaire.

\section{Review of Literature}

the adenoids were first described by danish physician, in 1885 gottstein described the first curette adenoidectomy $^{31}$. koltai et al 1997 and stain law et al 2000 conducted studies comparing powered assisted and curette adenoidectomy ${ }^{32-35}$.

\section{Observations}

As already discussed we had done prospctive analysis of 25 cases of adenoid hyper trophy

A. Age: most of the cases in our study was between 4 to 7 years

B. Sex: male to female ratio was 4:1 (19 male and 6 female child)

C. Urban vs Rural: 23 cases were of urban population

Table -1

\begin{tabular}{|l|c|c|}
\hline $\begin{array}{l}\text { Age of patient } \\
\text { (years) }\end{array}$ & No of cases & Percentage \\
\hline $3-4$ & 01 & $4 \%$ \\
\hline $4-5$ & 05 & $20 \%$ \\
\hline $5-6$ & 06 & $24 \%$ \\
\hline $6-7$ & 04 & $16 \%$ \\
\hline $8-9$ & 03 & $12 \%$ \\
\hline $9-10$ & 02 & $8 \%$ \\
\hline $10-11$ & 01 & $4 \%$ \\
\hline $11-12$ & 01 & $4 \%$ \\
\hline $12-13$ & 01 & $4 \%$ \\
\hline $17-18$ & 01 & $4 \%$ \\
\hline
\end{tabular}

Table 2 Operative variable for adenoidectomy in both techniques

Variable

\begin{tabular}{|c|c|}
\hline $\begin{array}{c}\text { powered asisited } \\
\text { adenoidectomy }\end{array}$ & $\begin{array}{c}\text { Curette } \\
\text { Adenoidectomy }\end{array}$ \\
\hline 1.adenoid removal time & \\
\hline 18 min(12 to 22$)$ & $28 \min (21$ to $32 \mathrm{~min})$ \\
\hline 2. estimated blood loss & \\
\hline $58(46$ to $65 \mathrm{ml})$ & $39(30$ to $46 \mathrm{ml})$ \\
\hline
\end{tabular}




\section{JMSCR Vol||07||Issue||03||Page 935-943||March}
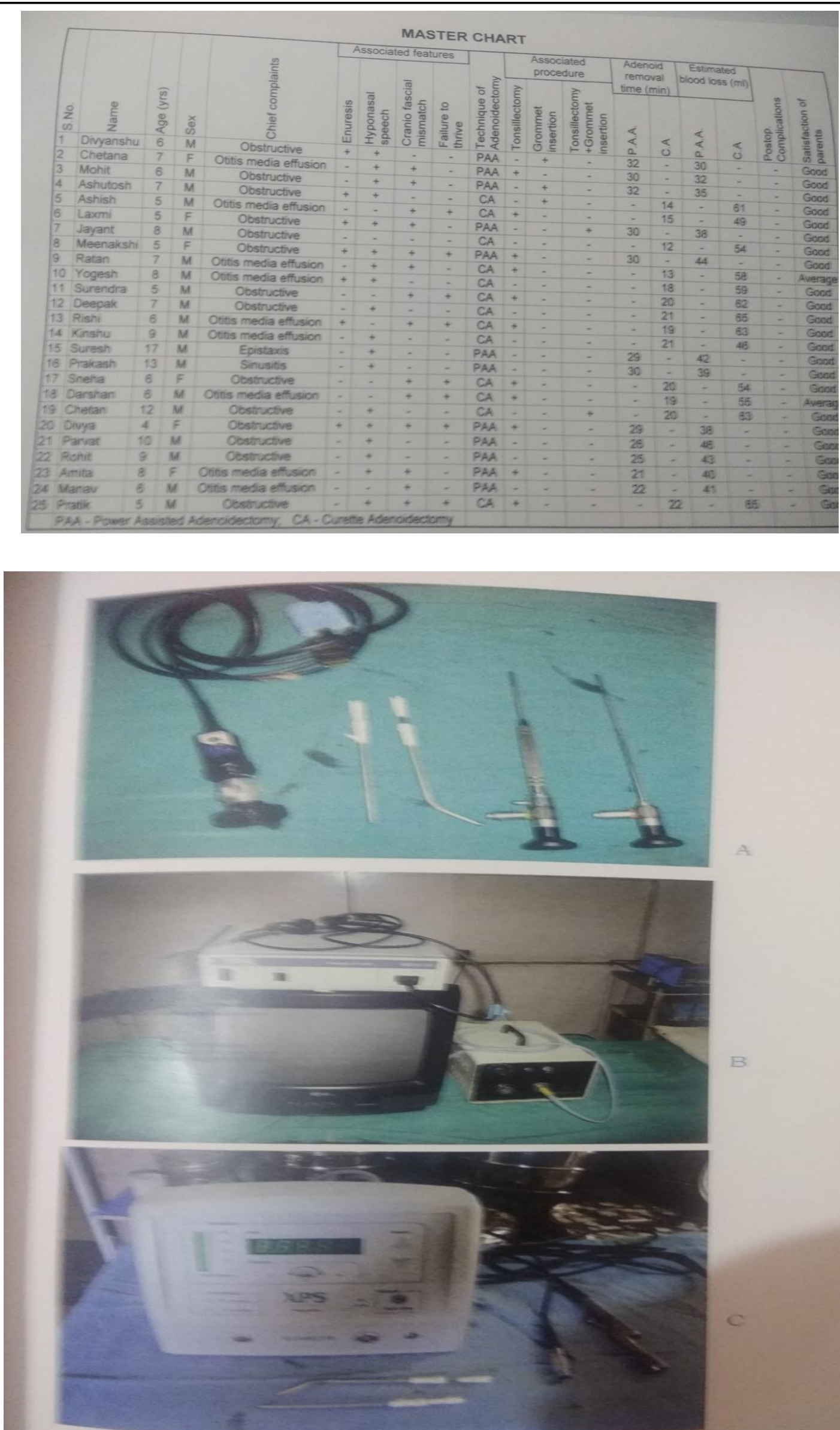


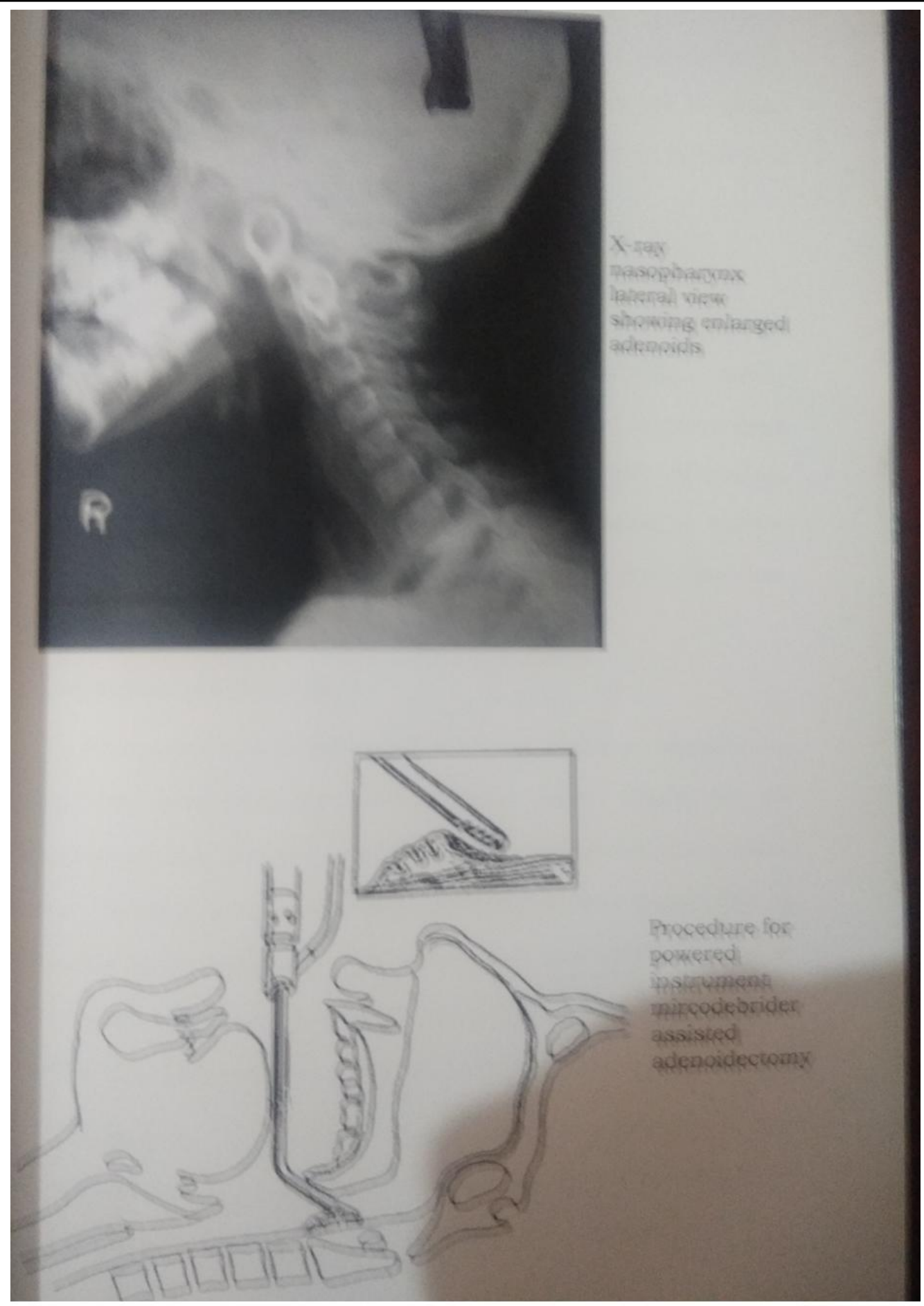

\section{Discussion}

Koltai et al (1997) 32-33 in their first study of powered assisted adenoidectomy, retrospectively compared operating time, amount of blood loss and length of postoperative stay. They found the mean operative time was significantly faster with powered assisted adenoidectomy (11 vs $19 \mathrm{~min}$. for currette adenoidectomy) whereas neither mean blood loss nor mean operative stay was significantly different from that in curette adenoidectomy group (22 vs $32 \mathrm{ml}$ and $2.95 \mathrm{hrs}$ vs $2.8 \mathrm{hrs})$,

Stainlaw (2000) et $\mathrm{al}^{35}$ also conducted PAA and compared results with curette adenoidectomy. $\mathrm{He}$ found PAA was $20 \%$ faster, $27 \%$ less blood loss and provided a more complete resection and better control of depth perception.

Rodriguez et ai $(2002)^{38}$ conducted a prospective study and found that adenoid removal time was significantly shorter with PAA than with curette 
adenoidectomy.

In the present study we compared the PAA with curette adenoidectomy. The newer aspect of our study was use of nasal endoscope in place of mirror. We observed that mean operative time was $28 \mathrm{~min}$ ( 21 to $32 \mathrm{~min}$ ) for PAA compared to $18 \mathrm{~min}$ (12 to $22 \mathrm{~min}$ ) for curette adenoidectomy which was contrary to the finding of earlier workers. We found that PAA to have longer operative time than curette adenoidectomy.

In our study mean estimated blood loss for PAA was $39 \mathrm{ml}$ (30 to $46 \mathrm{ml}$ ) compared to $58 \mathrm{ml}$ for curette adenoidectomy, this is similar to other studies as koltai et al found that mean estimated blood loss for PAA was $22 \mathrm{ml}$ compared to $32 \mathrm{ml}$ for curette adenoidectomy.

In this way results of our study for estimated blood loss are compareble to previous studies and statiscally significantl. less bleeding and better hemostasis with paa was best explained by the greater ability of the microdebrider to provide a precise dissection down to the less vascular plane of the tissue.

In our study long term benefits were of higher percentage with PAA.

Use of nasal endosope with camera in our study dramatically helped us for precise adenoidectomy. Hence it may be concluded from the present study that paa is a safe efficient and better method of adenoidectomy than conventional curette adenoidectomy and gives better and long lasting results.

\section{Summary}

$>60 \%$ cases of adenoid hypertrophy was found between 4 to 7 years of age.

Snoring was the chief complain among the children comprising $54 \%$ next was otitis media with effusion in $36 \%$, sinusitis $8 \%$ and epistaxis $4 \%$,

$>$ Craniofacial mismatched in $64 \%$ cases, enuresis in $28 \%$, hyponasal speech in $76 \%$,

$>$ Use of transnasal endoscope showed that superior most portion of the adenoid was the chief contributer in obstructing the posterior choana which is not seen by lateral neck radiography.

$>$ Mean operating time was 28 min for paa in contrast to $18 \mathrm{~min}$ for curette adenoidectomy thus paa took long operating time by $59 \%$.

$>$ Mean estimated blood loss for paa was 39 $\mathrm{ml}$ compared to $58 \mathrm{ml}$ for curette adenoidectomy thus $67 \%$ less in comparison to curette adenoidectomy.

$>$ There was not much difference in the course of immediate post operative period between the two techniques.

$>16 \%$ cases showed partial relief from previous symptoms in curette adenoidectomy at long term follow up while in the paa.

\section{Conclusions}

In the present study paa proved to be a more efficacious procedure in relation to precise adenoid removal, less blood loss, greater surgeon satisfaction, safety, good long term benefits. thus we conclude that powered assisted adenoidectomy is method of choice for adenoidectomy.

\section{Bibliography}

1. AREY LB: On development, morphology and interpretation of a system of crypts analogue in pharyngeal tonsil, AM J ANAT 80:203-233 1947.

2. SLIPKA J: The development and function of the pharyngeal tonsil in early ontogenesis, Cesk otolaryngol 30:201-206 1981.

3. ROSENFELD: RM: Pilot study of outcomes in pediatric rhinosinusitis, Arch otolaryngol head neck surg 121: 729,1995.

4. HOWIE AJ: Scanning \& transmission electron microscopy on the epithilium of human palatine tonsil, J PATHOL 130:191,1980

5. PALUMBO FM: Pediatric consideration of infection and inflammation of waldeyer $\mathrm{s}$ ring, Otolaryngol clin north am 
20:311,1987.

6. SNOOK T : The development of the human pharyngeal tonsil, Am j anat 55:323,1934.

7. RICHTSMEIER WJ ,SHIKHARI AM,WB SHAUNDERS: The physiology and immunology of the pharyngeal lymphoid tissue ,In otolaryngology clinics north am philadelphia ,1987,

8. MANDEL EM AND OTHERS : Effect of adenoidectomy on eustachian tube function: preliminary results of a randomized clinical trial, $\mathrm{Adv}$ otorhinolaryngol 47: 227,1992.

9. SURJAN L, BRANTZAEG P,BERDAL P : Immunoglobulin system of human tonsils , II. Patients with chronic tonsillitis or tonsillar hyperplasia : quantification of Ig producing cells, tonsillar morphology and serum ig concentration, Clin exp immunot 31:382,1978.

10. TEEL DW: Inflammatory diseases of the mouth \& pharynx . In BLUESTONE CD ,STOOL SE, editors : Pediatric otolaryngology ,philadelphia ,1983,WB SAUNDERS.

11. SIEGEL G: Theoretical and clinical aspects of the tonsillar functions, ,Int J Pediatric otorhinolaryngol 6:01, 1983.

12. OHLMS LA, WILDER RT, WESTON B: use of intraoperative corticosteroids in pediatric tonsillectomy ,Arch otolaryngol head neck surg 121: 737,1995.

13. D AMELIO R \& OTHERS: $S$ erum IgA in salivery levels in normal subjects : comparision between tonsillectomized and non tonsillevtomized subjects ,Int arch allergy appl immunol $68: 256,1982$.

14. DONOVAN R, SOOTHILL JF: Immunological studies in children undergoing tonsillectomy, Clin exp immunol 14: 347.1973.

15. OHLMS LA, WILDER RT,WETSON B :Use of intraoperative corticosteroids in pediatric tonsillectomy ,Arch otolaryngol head neck surg 121 : 737,1995 .
16. BROOK I : The clinical microbiology of waldeyer s ring, Otolaryngol clin am 20: $259,1987$.

17. STANISLAW P JR., KOLTAI PJ, FEUSTET PJ: Comparison of powered assisted adenoidectomy vs curette adenoidectomy, Arch otolaryngol head neck surg ,126: $845,2000$.

18. INGVARSSON L,LUNDGREN K, IRVING J: The bacterial flora in the nasopharynx in healthy children , Acta otolaryngol supll ( stockh) 386: 94, 1982.

19. BRODSKY L ,KOCH RJ : Bacteriology and immunology of normal and diseased adenoids in children, Arch otorhinolaryngol head neck surg 119: 821 ,1993.

20. BROOK I ,WALKER RL : Pathogenecity of anaerobic gram positive cocci ,Infect immun 45: $320,1984$.

21. BRODSKY L ,KOCH RJ: Bacteriology and immunology of normal \& diseased adenoids in children. Arch otolaryngol head neck surg $119: 821,1993$

22. RICHTSMEIER WJ : Human interferon production in tonsil and adenoid tissue cultures . Am j otolaryngol 4: 325,1983

23. LEACH J AND OTHERS: Polysomnographic and clinical findings in children with obstructive sleep apnea , Arch otolaryngol head neck surg 118: 741,1992.

24. TRASK G AND OTHERS : The effects of perennial allergy rhinitis on dental and skeleton development: A comparison of siblings , Am j orthod 92 : 286, 1987,

25. LINDER ARONSON S,WOODSIDE DG ,LUNDSTROM A : Mandibular growth direction following adenoidectomy, Am j orthod dentofacial orthop 89: $273,1986$.

26. OWEN GO , CANTER RJ ,ROBINSON A: Overnight pulse oximetry in snoring and non snoring children, Clin otolaryngol 20: 402, 1995.

27. FUJIOKA M, YOUNG LW, GIRDANY 
BR : Radiographic evalution of adenoid size in children : adenoid nasopharyngeal ratio ,Am j radio 133:401, 1979.

28. KORNBLUNT AD: A traditional approach to surgery of the tonsils and adenoids , Otol clin north Am 20: 349,1987.

29. PRATT LW, HORNBERGER HR,MOORE VJ : Mediastinal emphysema complicating tonsillectomy \& adenoidectomy, Ann otol rhinol laryngol 71: 158,1962

30. D AMELIO R \& OTHERS: S erum IgA in salivery levels in normal subjects: comparision between tonsillectomized and non tonsillevtomized subjects ,Int arch allergy appl immunol $68: 256,1982$.

31. THRONVAL A, WILHELM MEYER : Arch otolaryngeal head neck surg 90: 383 ,1969.

32. KOLTAI PJ: Powered innstruments in pediatric otorhinolaryngology, Arch otolaryngol head neck surg $14: 25,2000$.

33. KOLTAI PJ, CHAN J, YOUNES A: Powered assisted adenoidectomy : total and partial resection . Laryngoscope 112: 29, 2002.

34. KOLTAI PJ AND OTHERS : Powered assisted adenoidectomy : total and partial resection, Arch otolaryngol head neck surg 123: $685,1997$.

35. STANISLAW P JR, KOLTAI PJ, FENSTAL PJ : Comparison of powered assisted adenoidectomy vs curette adenoidectomy, Arch otolaryngol head neck 103: 966, 1990.

36. MURRAY NL, FITZPATRIC P, GUARISCO JL: Powered partial adenoidectomy : A clinical trial : Arch otolaryngol head neck surg ,2003

37. CLEMENS J, MCMURRAY JS ,WILLGING JP: Electrocuatery versus curette adenoidectomy : A comparison of prospective results, Int $\mathrm{j}$ peditr otolaryngol 43: 112- 115,1998 .
38. CRAIG S, DERKAM MD, BRIMI R: Innovative techniques for adenotonsillar surgery in children : Introduction and commentry ,Laryngoscope 112: 8,2002. 